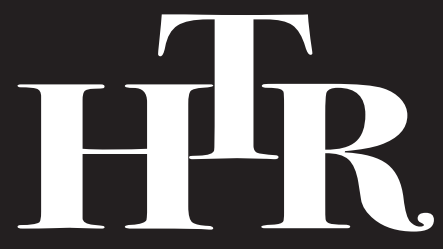

\title{
Harvard
}

Theological

Review

CAMBRIDGE UNIVERSITY PRESS
107:4 OCTOBER 2014 ISSN 0017-8160 
The Harvard Theological Review is partially funded by the foundation established under the will of Mildred Everett, daughter of Charles Carroll Everett, Bussey Professor of Theology in Harvard University (1869-1900) and Dean of the Faculty of Divinity (1878-1900). The scope of the Review embraces history and philosophy of religious thought in all traditions and periods - including the areas of Hebrew Bible, New Testament, Christianity, Jewish studies, theology, ethics, archaeology, and comparative religious studies. It seeks to publish compelling original research that contributes to the development of scholarly understanding and interpretation.

\title{
CO-EDITORS
}

Kevin J. Madigan and Jon D. Levenson

EDITORIAL BOARD

Giovanni Bazzana, Francis X. Clooney, David N. Hempton, Mayra Rivera
Rivera

ASSOCIATE EDITORS

Members of the Faculty of Divinity

MANAGING EDITOR

Margaret Studier

EDITORIAL ASSISTANTS

Timothy M. Baker, Faye Bodley-Dangelo, Margaret Butterfield, Eunyung Lim, Michael Motia, Kip Richardson, Malka Zeiger Simkovich, Adam Stern, Axel Takács

\section{PRODUCTION STAFF}

\author{
Faye Bodley-Dangelo, Margaret Butterfield, Maria Metzler, Michael Motia, \\ Kynthia Margaret Taylor
}

Manuscripts and communications on editorial matters should be emailed to htr@hds.harvard.edu or mailed to the Managing Editor, Harvard Theological Review, Harvard Divinity School, 45 Francis Avenue, Cambridge, MA 02138. Instructions to contributors and a full style guide may be downloaded from www.journals.cambridge.org/htr/ifc.

Harvard Theological Review (ISSN 0017-8160; e-ISSN 1475-4517) is published four times a year in January, April, July, and October. The subscription prices, which include delivery by air where appropriate (but excluding VAT), for volume 107, 2014 are: individuals, online only: \$42/£26; individuals, print and online: $\$ 63 / £ 42$; individuals (AAR, SBL, Langham Scholars), print only $\$ 38 / £ 23$; institutions, online only $\$ 210 / £ 127$; institutions, print and online $\$ 262 / £ 159$; institutions, print only: $\$ 239 / £ 148$. Single issues are available for $\$ 60 / £ 37$. EU subscribers (outside the UK) who are not registered for VAT should add VAT at their country's rate. VAT registered members should provide their VAT registration number. For all subscriptions queries in the USA, Canada, and Mexico, email subscriptions_newyork@ cambridge.org, call (845) 353-7500 or write to Cambridge University Press, 32 Avenue of the Americas, New York, NY 10013-2473, USA. For subscription queries elsewhere in the world email journals@ cambridge.org, call +44 (0)1223 326070 or write to Cambridge University Press, The Edinburgh Building, Shaftesbury Road, Cambridge CB2 8BR, UK. For advertising queries contact ad_sales@cambridge.org.

Photocopying information: Permission to copy (for users in the USA) is available from the Copyright Clearance Center: www.copyright.com or email: info@copyright.com. For all other reuse, permission must be sought from Cambridge University Press.

The foreign language and transliteration fonts used in this journal are available from Linguist's Software Inc., PO Box 580, Edmonds, WA 98020-0580 USA; tel: (425) 775-1130; website: www.linguistsoftware.com.

Published by Cambridge University Press, New York, New York

(C) Copyright by the President and Fellows of Harvard College, 2014 


\section{Harvard Theological Review}

$107: 4$

OCTOBER 2014

\section{ARTICLES}

Confessing Incest to a Rabbi: A Talmudic Story in Its

Zoroastrian Context

Yishai Kiel

Blind Men Speaking of Colors: Paul's Recollection and the

425

Self-Image of Early Thirteenth-Century Theologians

Ayelet Even-Ezra

The Conflation of Purity and Prohibition: An Interpretation of

Leviticus 18:19

Michael Rosenberg

Was Priscillian a Modalist Monarchian?

470

Tarmo Toom

Making the Case for the Soul in an Age of Neuroscience

485

Alan Mittleman

Summaries of Doctoral Dissertations

495

Books Received

505

Index 